\title{
Investigation of freight rail transport in worldwide logistics important area Port of Antwerp: A review
}

\author{
Lucia Knapčíková $^{1 *}$,Michal Balog ${ }^{1}$ \\ \{lucia.knapcikova@tuke.sk, michal.balog@tuke.sk\}
}

\begin{abstract}
Technical University of Košice, Faculty of Manufacturing Technologies with a seat in Prešov, Department of Industrial Engineering and Informatics, Bayerova 1, 08001 Prešov, Slovak Republic ${ }^{1 *}$

Technical University of Košice, Faculty of Manufacturing Technologies with a seat in Prešov, Department of Industrial Engineering and Informatics , Bayerova 1, 08001 Prešov, Slovak Republic ${ }^{1}$
\end{abstract}

\begin{abstract}
The situation with the road transportation inspires companies to think more and more about alternative ways of transporting goods from remote industrial zones quickly, safely and taking into account an ever more important environmental aspect. The quantity of goods transported in freight transport is increasing every year, which is also reflected in the unfavourable increase in road transport. Road transportation is often used, roads are more prone to wear, and their repair requires significant financial costs each year. The traffic situation proves that the future is using rail transportation. Moving freight from road to rail is also the intention of the European Union, which is declared in the "White Paper on Transport". In addition to other targets, it states that by the year 2030, 30\% of road freight over $300 \mathrm{~km}$ should be transferred to other modes of transport such as rail or inland waterway transport, and by the year 2050 , this should be represent more than $50 \%$.
\end{abstract}

Keywords: Port Antwerp, logistics, railway solution

\section{Introduction}

The Port of Antwerp lies on the banks of the river Schelde about 88 kilometers from the North Sea in Belgium. Antwerp is the capital of Flanders, one of Belgium's three regions, the Port of Antwerp is about 43 kilometers east-northeast of the Port of Ghent and about 45 kilometers north of the Port of Brussels. The Port of Antwerp is one of the world's busiest seaports. Over 472 thousand people live in the city, and almost 1.2 million people call the metropolitan area home. [1],[2] In 2005, the American Association of Port Authorities reported that the Port of Antwerp was the second busiest port in Europe and the 17th busiest in the world (defined by the amount of cargo handled) in 2005. The Port of Antwerp focuses on bulk, general and project cargoes. It is also home to the second largest petrochemical industrial complex in the world, after Houston, Texas. The Port of Antwerp is also one of the world's most important centers for the diamond trade.[1]

The Port of Antwerp is the most important hub. The railway sector offer a safe, reliable and primarily environmentally friendly means of transport for the supply and distribution of its products in Belgium and across Europe.[3] 


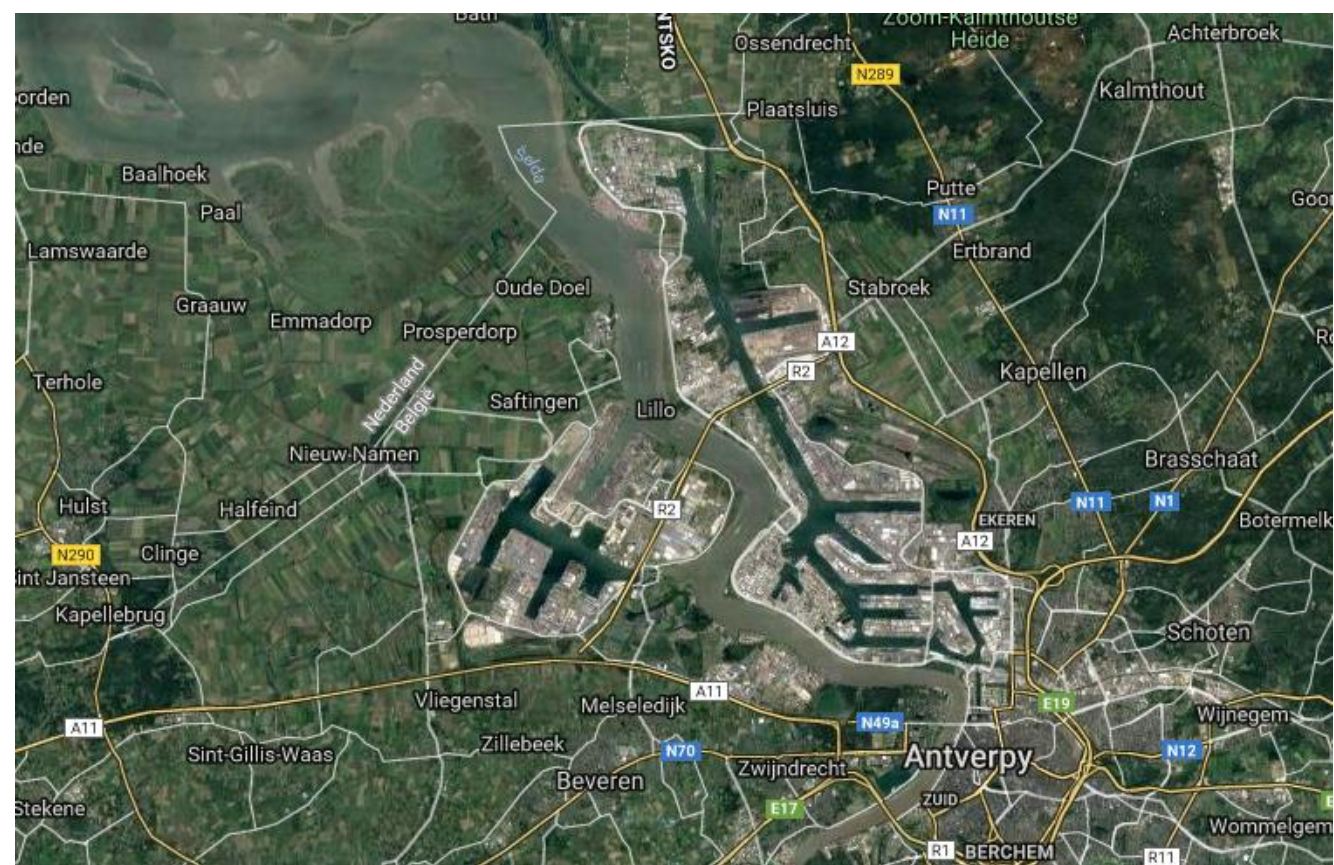

Fig. 1. Port of Antwerp (satellite view) [8]

\section{Rail transport in the Port of Antwerp}

Antwerp is one of the biggest European rail ports with over 24 million tonnes of cargo are transported by rail every year. The Port of Antwerp aims to further increase the share of freight transport by rail. This is why different services and initiatives have been developed to guarantee customers are able to transport their goods efficiently and reliably. Antwerp is an outstanding rail port. It is a junction of the major rail connections inside and outside Europe. [3] Service providers invest heavily in a rail offering to make it as quick and flexible as possible. Rail allows a significant reduction of the ecological footprint. For the majority of cargo flows it is a valid alternative to road transport. [4]

The port of Antwerp is a centrally located (Fig.2) railway junction for the three main rail corridors in Europe:

- Corridor 1 (Rhine - Alpine Corridor): Antwerp - Duisburg - Cologne - Basel Genoa

- Corridor 2 (North Sea - Mediterranean Corridor): Antwerp - Luxembourg Lyon/Strasbourg - Basel

- Corridor 8 (North Sea - Baltic Corridor): Antwerp - Duisburg - Poland - Lithuania Moreover trains regularly leave from Antwerp to destinations outside Europe such as Russia, Kazakhstan and China. [3] 


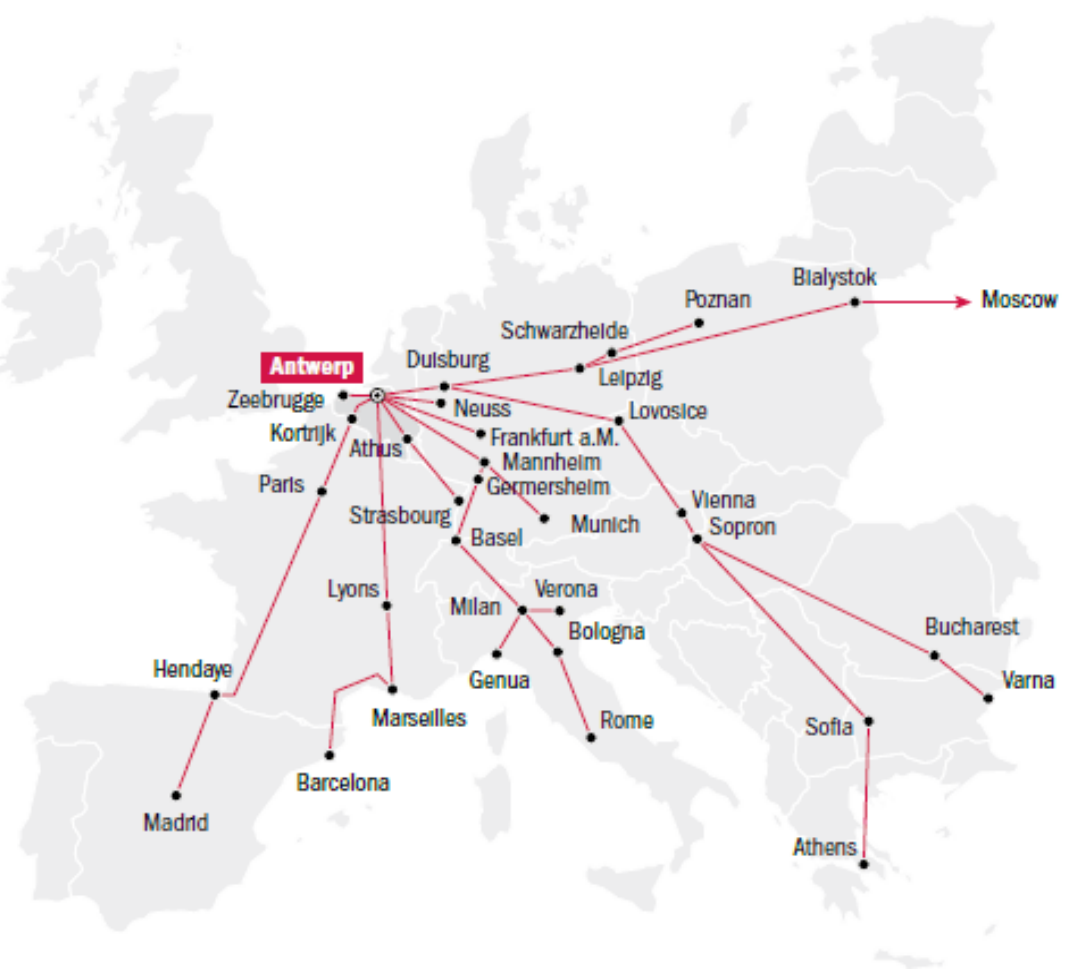

Fig. 2. Port of Antwerp, an European railway junction [3]

Many private rail companies and rail operators invest actively in direct international rail connections with the Port of Antwerp for all forms of shipment. This wide choice of specialised providers guarantees a varied offer.[1], [3]

A list of rail dispatching agents active in Antwerp:

- Rail\&Sea

- IRP

- $\quad$ RT Chem

- Kuehne + Nail Rail Logistics

A list of rail operators active in Antwerp:

- IFB

- HUPAC

- Optimodal Kombiverkehr

- Cemat

- MSC Medlog

- Duisport Rail

- Bulkhaul

- Naviland

- Cargo 
- CGM

- IFB/Lineas

- $\mathrm{CFL}$

- Greenmodal

- Quadrum Raillogistics en CFL Multimodal [3]

The Liefkenshoek rail link is a 16,2 km (Fig.3) connection between the Left and Right bank of the Scheldt river. This rail link started operation in December 2014 and has a capacity of 109 freight trains per day in each direction. It offers a time saving of more than half an hour while affording greater reliability of operation.[3],[4]

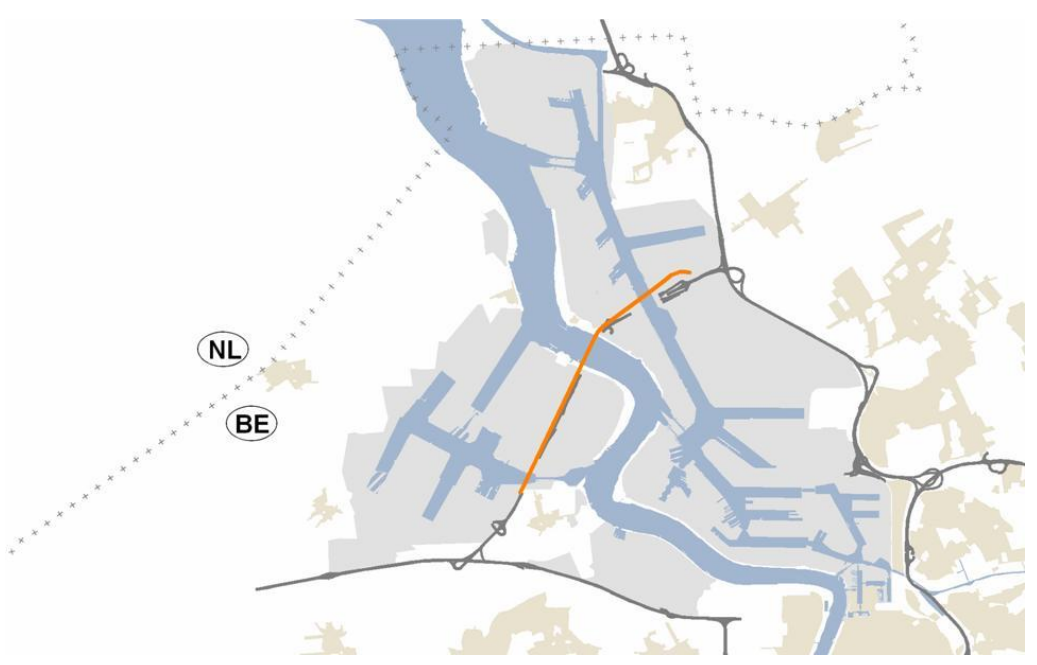

Fig.3 The Liefkenshoek rail tunnel [3]

Rail access to the port on the right bank will improve in the coming years with the construction of a fly-over, among other things. This should increase the capacity of the principal access rail by approximately $30 \%$ to guarantee the growth of rail transport over time. In the long term the aim is to achieve further capacity growth by the construction of a completely new, second rail access. The final design should be agreed upon in the coming years.[2], [3]

A renewed, high-quality rail connection for Antwerp with the German area of NordrheinWestphalia via the Iron Rhine route is also on the agenda. This railway line gives the Port of Antwerp a direct and cost efficient connection with the principal German and Central European rail networks and regions. Reopening the Iron Rhine would be a perfect supplement to the Montzen route connecting Antwerp and Aachen. [3] 


\section{Transportation of freight rail in the Port of Antwerp}

Terminals in the port area, are certified to strip and stuff containers with dangerous cargo. These companies need a license to operate this container freight station from the Chief Harbour Master. [7]

Tab.1 List of the certified container of freight stations in the Port of Antwerp [7]

\begin{tabular}{|l|l|c|}
\hline \multicolumn{1}{|c|}{ Operator } & \multicolumn{1}{c|}{ Location } & Code \\
\hline Deufol & Beliweg - quay 317 & ACECFS \\
\hline Belgian New Fruitwharf & Albertdok - quay 188 & BNF188 \\
\hline Belgian New Fruitwharf & Leopolddok - quay 210 & BNF210 \\
\hline Belgian New Fruitwharf & Leopolddok - quay 220 & BNF220 \\
\hline Carga N.V. & Haven 550 - at portnumber 532 & ALPHAN \\
\hline DP World & Deurganckdok, quay 1702 & AGWCFS \\
\hline Handico Terminals N.V. & Luithagen 12 & HANDIC \\
\hline $\begin{array}{l}\text { Kroon Service Logistics \& } \\
\text { Warehousing N.V. }\end{array}$ & Noorderlaan 123 & KSLCFS \\
\hline Transport Joosen & Bellestraat 2 & JOOSEN \\
\hline PSAHNN N.V. & S853 & HNCFS6 \\
\hline PSAHNN N.V. & Deurganckdok, quay 1742 & DGTCFS \\
\hline Seaport Terminals N.V. & Haandorpweg 1 - at portnumber 1227 & SWITZ \\
\hline $\begin{array}{l}\text { Valkeniersnatie Storage N.V. } \\
\text { (Katoen Natie) }\end{array}$ & $\begin{array}{l}\text { Tractorweg } \\
\text { Warehouse Antverpia 3 }\end{array}$ & ANTCFS \\
\hline Van Aerde N.V. & St. Jansweg 9 - at portnumber 1602 & VAERDE \\
\hline Waagnatie N.V. & Leopolddok - at portnumber 218 & WAGCFS \\
\hline Th. Wouters Transport & Klein Zuidland 4 & WOUTER \\
\hline Wijngaardnatie & $\begin{array}{l}\text { CONPACK } \\
\text { Haminastraat 15 - at portnumber 73 }\end{array}$ & CONCFS \\
\hline Zuidnatie N.V. & $\begin{array}{l}\text { Terminal Zuidnatie, kaai 118 - magazijn } \\
\text { 3 }\end{array}$ & ZUID2 \\
\hline
\end{tabular}

Almost one-fourth of all containers (23.9\% of all containers) travelled through the Port of Antwerp to/from Europe. Almost two million containers (21.3\% of all containers) travelled to/from the Near East. Over 1.3 million TEUs (15.5\% of all containers) travelled to/from the Middle and Far East, and 1.6 million TEUs (19.3\% of all containers) travelled through the Port of Antwerp to/from North and Central America. Of the four million containers leaving the Port of Antwerp, 37\% were loaded back onto ocean-going vessels, $12 \%$ were delivered to companies within the Port of Antwerp, $16 \%$ were sent into Belgium, and 35\% were delivered to neighbouring countries. The transport of dangerous goods by rail has recently been up to date, particularly in terms of its safety. They serve the industry and consumers every day, and there is an endeavour to provide them with technical and technological innovations, but focusing on this is not enough. [7] 
The Table 2 describes a statistical data processing of the volume of freight rail transport that has been monitored and processed from 2006 to comparison on previous statistics data, mentioned above.

Developing implementation studies and strategic approaches in the long run also need to be addressed.

Tab.2 Volume of freight rail transport in the Europe [9]

\begin{tabular}{|c|c|c|c|c|c|c|c|c|c|c|}
\hline GEOITIME & 2006 & 2007 & 2008 & 2009 & 2010 & 2011 & 2012 & 2013 & 2014 & 2015 \\
\hline European Union (28 countries) & 100.4 & \begin{tabular}{|r|}
100.9 \\
\end{tabular} & 98.8 & 91.5 & 94 & 92.6 & \begin{tabular}{r|}
90.7 \\
\end{tabular} & 91.6 & \begin{tabular}{r|}
90.4 \\
\end{tabular} & 90.1 \\
\hline Belgium & 98.9 & 94.1 & 86.7 & 78.6 & 79.5 & 75.6 & 75.3 & 76.3 & 73.8 & 72.5 \\
\hline Bulgaria & 92 & 89.7 & 92.8 & 110.6 & 118.4 & 117.3 & 132.7 & 144.1 & 144.8 & 159.6 \\
\hline Czech Republic & 106.1 & 97.9 & 98.1 & 89.8 & 99.7 & 103 & 98.4 & 103.9 & 100.9 & 101.8 \\
\hline Denmark & 88.1 & 85.8 & 81 & 74.1 & 67.6 & 72.4 & 73.1 & 70.7 & 70 & 65.7 \\
\hline Germany (until 1990 former territory of the FRG) & 102.9 & 104 & 102.5 & 95.7 & 96.7 & 95.1 & 91.4 & 91.5 & 90.7 & 90.1 \\
\hline Estonia & 87.9 & 75.9 & 71.9 & 71.5 & 75.9 & 70.2 & 60.3 & 58.3 & 50.7 & 49 \\
\hline Ireland & 91.6 & 95.7 & 91.5 & 64.4 & 59.2 & 54.8 & 54.6 & 50 & 48.8 & 39.2 \\
\hline Greece & 134.6 & 107.6 & 111.8 & 114.9 & 126.9 & 96.2 & 104.6 & 98.3 & 99.6 & 102.5 \\
\hline Spain & 99.3 & 102.1 & 94.9 & 85.1 & 84.9 & 84.7 & 84.1 & 82.8 & 83.4 & 86.5 \\
\hline France & 100.3 & 101.5 & 95.5 & 82.6 & 83.7 & 84.7 & 79 & 78.2 & 75.4 & 70.7 \\
\hline Crostia & 105.6 & 104.8 & 110 & 100 & 98.1 & 96.2 & 95.8 & 98.8 & 101.2 & 110 \\
\hline |taly & 88.3 & 84.3 & 85 & 81.7 & 84.2 & 70.1 & 63.9 & 66 & 62.1 & 61.5 \\
\hline Cyprus & 80 & 78.8 & 82.5 & 61.9 & 68.9 & 59.5 & 58.5 & 44 & 37.9 & 39 \\
\hline Latuia & 87.5 & 90.9 & 95.6 & 93.8 & 100.8 & 114.5 & 111.7 & 103.5 & 103.7 & 102.4 \\
\hline Lithuania & 101.9 & 102.4 & 1013 & 100.2 & 109.2 & 114.8 & 113.6 & 115.8 & 119.4 & 112.2 \\
\hline Lusembourg & 96 & 96.4 & 89.6 & 86.5 & 87.1 & 85.4 & 77 & 79.9 & 83.6 & 74 \\
\hline Hungary & 112.7 & 126.7 & 125.2 & 125.5 & 124.8 & 124.2 & 124.8 & 129 & 129.3 & 127.1 \\
\hline Malta & 98.2 & 94.4 & 91.4 & 93.7 & 90.5 & 89.3 & 87 & 83.2 & 76.9 & 71.5 \\
\hline Netherlands & 96.3 & 92.7 & 91 & 83.6 & 91.8 & 89.6 & 87.3 & 89.6 & 89.1 & 84.8 \\
\hline Austria & 103.9 & 99.2 & 93.3 & 80.8 & 82.6 & 80.6 & 74.9 & 71.8 & 73.1 & 71.7 \\
\hline Poland & 105.9 & 111.5 & 113.1 & 113.6 & 122.7 & 121.7 & 124.3 & 134.9 & 131.7 & 131.2 \\
\hline Portugal & 103.4 & 104.1 & 88.7 & 83.4 & 81.2 & 85.1 & 80.8 & 89.8 & 85.5 & 77.9 \\
\hline Romania & 98.2 & 94.4 & 83.8 & 64.1 & 59.5 & 58.8 & 61.9 & 63.6 & 61.7 & 66.1 \\
\hline Slovenia & 102.7 & 107.5 & 118.7 & 114.4 & 124.4 & 129 & 127.1 & 130.8 & 131.2 & 138.9 \\
\hline Slovakia & 92.7 & 98 & 97.3 & 92.3 & 91 & 91.4 & 90.4 & 92.3 & 93.2 & 93.4 \\
\hline Finland & 94.3 & 88.6 & 91.3 & 87.3 & 90.8 & 81.7 & 79.5 & 78.2 & 76.6 & 76.3 \\
\hline Sweden & 98.6 & 97.8 & 100.7 & 90.1 & 91.6 & 89.4 & 83.2 & 80.7 & 91.3 & 86.1 \\
\hline United Kingdom & 100 & 100.1 & 95 & 86.9 & 88.8 & 92.4 & 94 & 87 & 82.2 & 88.1 \\
\hline Norway & 103.6 & 101.3 & 106.8 & 98.4 & 103.6 & 100.5 & 101.6 & 105.1 & 104.9 & 109.4 \\
\hline Switzerland & 100.7 & 97.2 & 85.9 & 79.6 & 79.2 & 80.3 & 76.1 & 76.6 & 77.4 & 75.2 \\
\hline Former Yugoslau Republic of Macedonia & 110.2 & 131.1 & 118.7 & 79.7 & 81.5 & 72.6 & 64.4 & 62.3 & & \\
\hline
\end{tabular}

As one of the few countries, Finland has set up a comprehensive strategic plan for the transport of hazardous costs for the period up to 2015, which deals not only with the state but also with the challenges and new trends that are useful as a source of inspiration for other countries, including Slovakia. In this country, there is a particular unit.

The institutions are responsible for this hazardous goods transport strategy and also responsible for preparing the necessary legal framework. [9]

It focuses on improving and developing supervision and management, education and services. 


\section{Suggested solutions of rail transport}

The Antwerp Port Authority is developing numerous strategic partnerships with hinterland hubs and terminals to enhance the port's competitiveness. This neutral service desk closely cooperates with terminals, intermodal operators and cargo owners to facilitate new intermodal services or to increase the frequency of existing ones with European growth regions that currently have little or no connections with Antwerp. [5], [3]

Objectives of the intermodal cell of Antwerp are:

- bringing new target regions within the reach of the port by means of new intermodal solutions;

- $\quad$ positively influencing the modal split.

The port aims to be the hub of European multimodal transport and offer integrated solutions, from foreland to hinterland. [1],[3]

Some strategic partnerships with hinterland partners (Fig.4):

- Collaboration extended gateway Antwerp-Limburg, Terminal ETG Genk

- Collaboration Port of Genk,

- Collaboration Port of Brussels,

- Collaboration Liège Trilogiport,

- Collaboration Port of Duisburg,

- Participation Antwerp East NV (operated by DP World),

- Participation Rail Terminal Chemelot (RTC) [3]

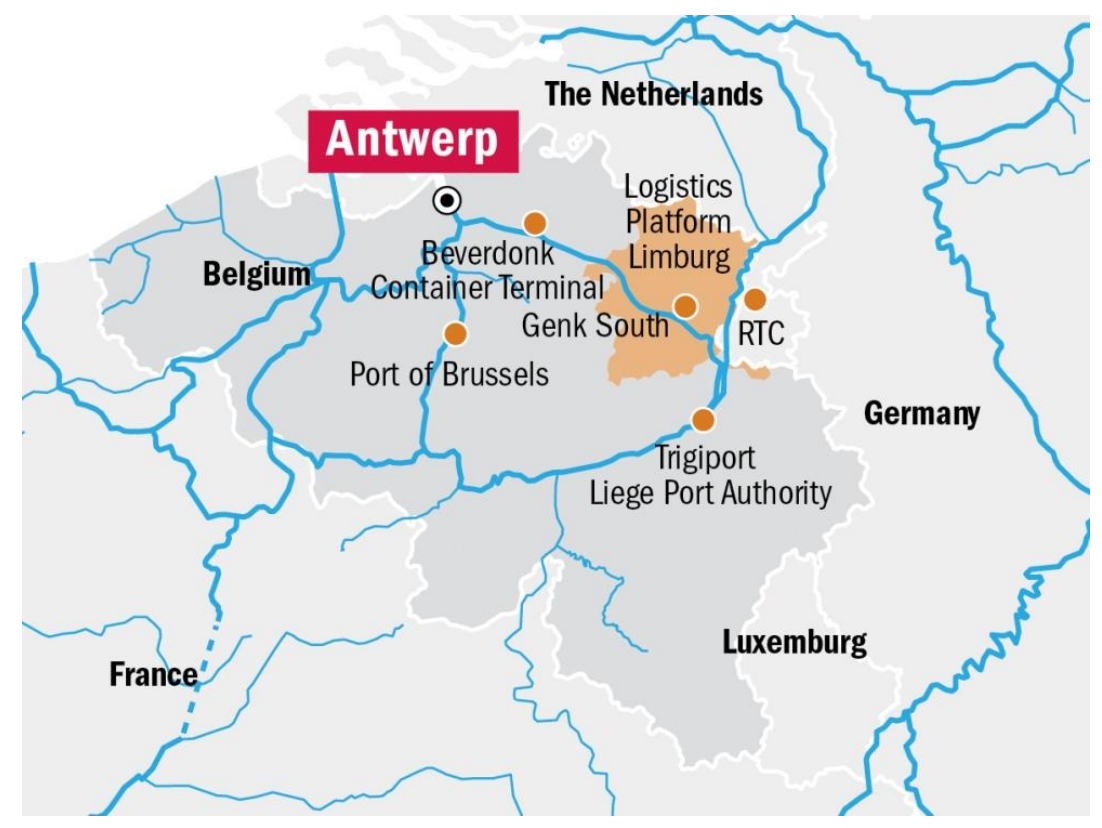

Fig. 4 Collaboration Port of Antwerp with hinterland partners [3] 
The Port Authority provides the right preconditions for the rail market, as follows:

- Work on specialised rail shunting services, an open system for the transport within the port, uniform shunting-engines and the neutral use and operation of the shunting bundles,

- Construct an open installations for the maintenance of wagons and engines,

- Development of a transport buffer for hazardous goods railcars (according to RID)

- Operational improvements for easy rail access.

\section{Conclusion}

The Port of Antwerp is very important area for railway connection across the Europe, but not only in Europe. The port area is practically in the centre of a big railway network running through Europe. This rail network has destinations varying from Spain to Norway and from Greece to Poland. Every week trains go to 70 destinations in 19 countries. [6] All terminals in the Port of Antwerp are connected to the railway network.

Presented work described an overview of transportation of freight rail in the Port of Antwerp. After analysis we can say:

- More than $1000 \mathrm{~km}$ of internal rail tracks,

- More than 250 goods train per day,

- Port of Antwerp prefer Just in Time- logistics method,

- Possibilities of parking facilities for RID wagons,

Transport and storage of chemical products are governed by strict regulations

\section{Acknowledgments}

This paper is part of a project that has received funding from the European Union's Horizon 2020 research and innovation programme under grant agreement No. 723274.
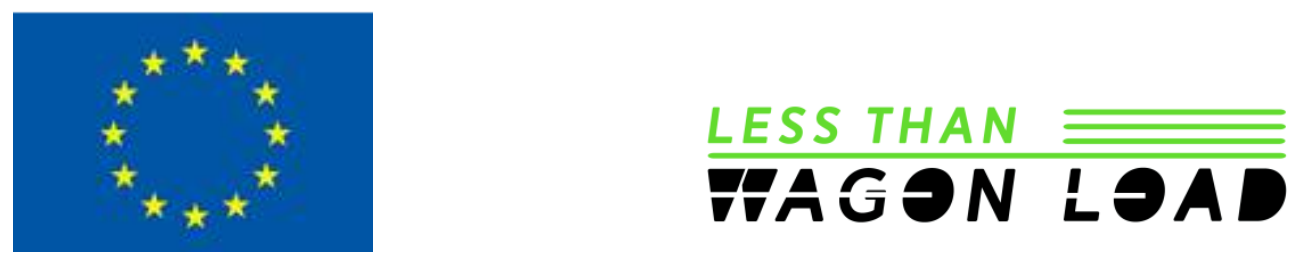

http://www.lessthanwagonload.eu 


\section{References}

[1] The Port of Antwerp [online] Available on http://www.worldportsource.com/ports/review/BEL_Port_of_Antwerp_25.php

[2]Balog M., Husár J., Knapčíková L., Šoltýsová Z.:Automation monitoring of railway transit by using RFID technology. Acta Technológia.(2015).

[3]Port of Antwerp. Available on http://www.portofantwerp.com

[4]Balog, M.,Mind'aš, M..Informatization of Rail Freight Wagon by Implementation of the RFID Technology, In: International Summit Smart City 360 . - Switzerland : Springer Verlag, pp. 592-597. - ISBN 978-3-319-33680-0. (2016).

[5]Balog, M., Šimeková, Ž., Semančo, P. Smart vehicle railroad,In: Applied Mechanics and Materials : Logistics Development : CLC 2014. Vol. 708, pp. 148-152. (2015).

[6] Transport from and to the port. [online]. Available on http://www.portofantwerp.com/en/transport-and-port

[7] Freight transportation in Port of Antwerp. [online] Available on https://www.portofantwerp.com/en/certified-container-freight-stations

[8] World port source. [online] Available on http://www.worldportsource.com/ports/maps/BEL_Port_of_Antwerp_25.php

[9] Goods transport by rail . [online] Available on

<http://ec.europa.eu/eurostat/tgm/graph.do?pcode=ttr00006\&language=en> 